\title{
Friedreich's Ataxia: Malic Enzyme Activity in Cellular Fractions of Cultured Skin Fibroblasts
}

\author{
S.B. Melançon, R. Cloutier, M. Potier, L. Dallaire, M. Vanasse, G. Geoffroy, A. Barbeau
}

\begin{abstract}
We have measured the activity of malic enzyme NADP + dependent in the nuclear, mitochondrial, lysosomal and cytosolic fractions of cultured skin fibroblasts from twelve patients with Friedreich's ataxia and nine control subjects. Hexosaminidase, cytochrome-C-oxidase, lactate dehydrogenase and malic enzyme NAD + dependent were used as marker enzymes. The activity of malic enzyme NADP + dependent was not significantly reduced in the mitochondrial fraction of patients with Friedreich's ataxia as compared with controls. When corrected for possible contamination between mitochondrial and cytosolic fractions, malic enzyme NADP + dependent activity was still not significantly reduced in patients with Friedreich's ataxia. Unless critical methodological differences were overlooked in this or previously published studies, we conclude that mitochondrial malic enzyme deficiency is not the primary genetic defect underlying Friedreich's ataxia.
\end{abstract}

RÉSUMÉ: Nous avons mesuré l'activité de l'enzyme malique NADP + dépendante dans les fractions nucléaires, mitochondriales, lysosomiques et cytosoliques de fibroblastes cutanés en culture, provenant de douze patients atteints d'ataxie de Friedreich et de neuf sujets normaux. Nous avons utilisé comme enzymes de référence l'hexosaminidase totale, la cytochrome-C-oxidase, la lactate déshydrogénase et l'enzyme malique NAD + dépendante. Nous n'avons pas réussi à mettre en évidence de déficit significatif en enzyme malique NADP + dépendante dans la fraction mitochondriale des fibroblastes cutanés provenant des patients ataxiques même après correction pour une contamination possible entre les fractions mitochondriales et cytosoliques. A moins qu'il ne s'agisse d'un artefact méthodologique implicable à notre étude ou aux études précédentes incriminant l'enzyme malique mitochondrial, il n'y a pas de rapport universel entre le déficit en enzyme malique et l'ataxie de Friedreich.

Can. J. Neurol. Sci. 1984; 11:637-642

In the past six years two closely related enzymatic defects have been proposed in order to explain the reduced rate of pyruvate oxidation observed after an oral load of glucose in patients with Friedreich's ataxia (FA) (Barbeau et al., 1976). First Blass et al. (1976) suggested that the pyruvate deydrogenase complex (PDH), in particular lipoamide dehydrogenase (LAD), the third composent of $\mathrm{PDH}$, was defective in patients with FA (Kark and Rodriguez-Budelli, 1977). However Melançon et al. (1975) and Stumpf et al. (1979) were unable to confirm these results using skin fibroblasts from two different groups of patients with typical FA.

More recently Stumpf et al. (1982) reported a 90 percent reduction in the activity of mitochondrial malic enzyme (MEm) in cultured skin fibroblasts of patients with FA. Their data became more significant from a genetic point of view when fibroblasts from obligate heterozygotes were shown to have intermediate levels of MEm activity (Stumpf et al., 1983), sug- gesting that MEm deficiency is geneticaly determined and that a mutation in MEm gene(s) could account for the pyruvate oxidation defect leading to neurological disease.

Using skeletal muscle from patients with FA, Bottacchi and Di Donato (1983) demonstrated a 60 percent decrease in mitochondrial ME and a 250 percent increase in cytosolic ME activity. Their data were in agreement with the previous results of Stumpf et al. (1982) but could also be interpreted in other ways since total ME activity (mitochondrial and cytosolic) found in patients was comparable with controls.

We have tried to confirm these data by measuring malic enzyme and three marker enzymes in cellular fractions of cultured skin fibroblasts from FA patients and normal controls. Although we have taken great care in trying to avoid leakage of mitochondrial enzymes toward the cytosolic supernatant, we have not been able to confirm the presence of a decreased malic enzyme activity in fibroblasts of our patients with F.A. 


\section{METhodology}

Skin biopsies were performed in nine normal controls (age 1 to 32) and twelve patients (age 11 to 33) with typical FA according to the criteria of Geoffroy et al. (1976). Skin implants were cultured in Eagle MEM (Flow laboratories) supplemented with 10 percent fetal calf serum inactivated at 56 degrees for 1 hour. Confluent cell layers from 8 to $16 \mathrm{~T}-150$ flasks (CORNING) were harvested by scraping in cold normal saline and centrifuged at $100 \mathrm{Xg}$ for $10 \mathrm{~min}$ at 4 degrees. The fresh cell pellet was homogenized in $0.25 \mathrm{M}$ sucrose, $2 \mathrm{mM}$ EDTA using a Pottertype glass homogenizer (PYREX \#7727). Microscopic examination revealed that most cells were broken after 50 strokes. Differential centrifugation was immediately performed using a Beckman model J2-21 refrigerated centrifuge as follows: $600 \mathrm{X}$ $\mathrm{g}$ for $10 \mathrm{~min}=$ nuclear pellet $; 8000 \mathrm{Xg}$ for $10 \mathrm{~min}=$ mitochondrial pellet; $60,000 \mathrm{Xg}$ for $30 \mathrm{~min}=$ lysosomal pellet and cytosolic supernatant. The fractions were frozen at -70 degrees until analysis: After thawing the cell pellets were dispersed in $1 \mathrm{ml}$ of sucrose-EDTA and submitted to ultrasounds using an ARTEK sonic dismembrator as follows: Nuclei $4 \times 5 \mathrm{sec}$, mitochondria and lysosomes $2 \times 5 \mathrm{sec}$, with cooling intervals of $10 \mathrm{sec}$ in ice. After centrifugation at $100 \mathrm{Xg}$ for $10 \mathrm{~min}$ the supernatants were ready for assay.

Malic enzyme NADP + dependent (ME-NADP + ) was assayed by the method of Lin and Davis (1974) modified by Bottacchi and Di Donato (1983). Malic enzyme NAD + dependent was determined as above, NAD replacing NADP in the reaction mixture. Lactate dehydrogenase $(\mathrm{LDH})$ was measured as in Stumpf et al. (1982). Cytochrome-C-oxidase (CCO) determination was taken from Sottocasa et al. (1967). The above assays were performed at 25 degrees using a Perkin-Elmer Lambda 3

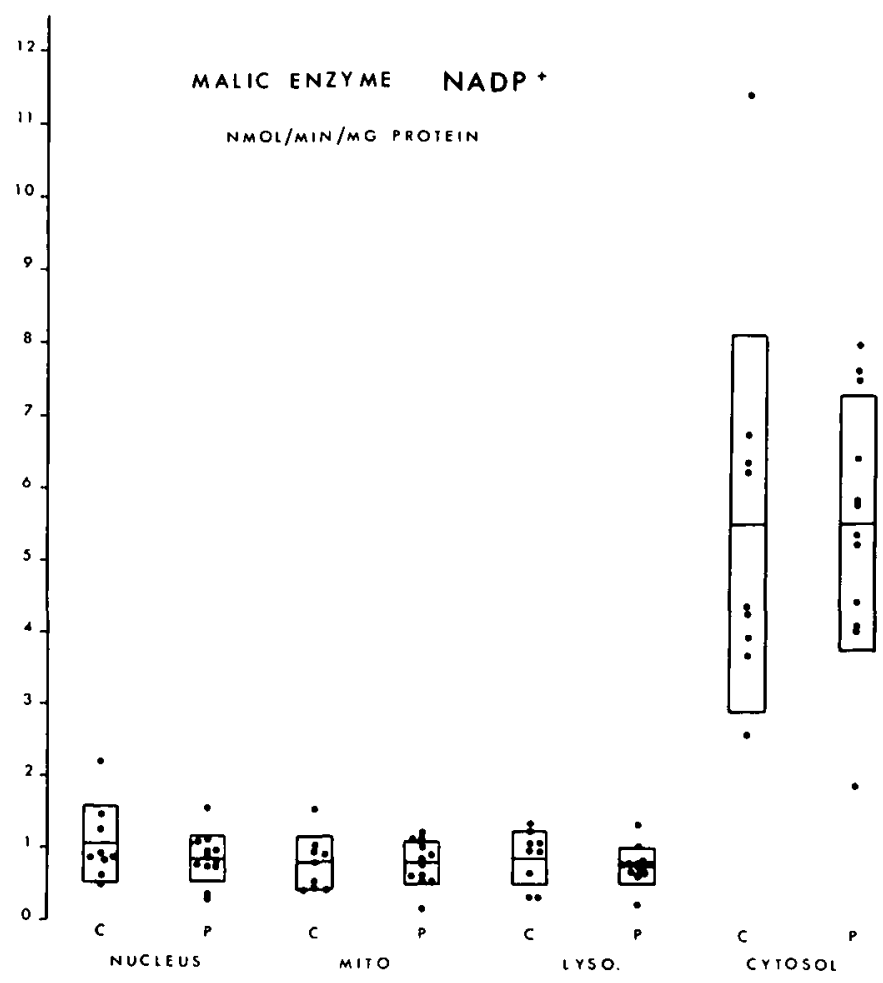

Figure I - Malic enzyme NADP + dependent activity in cellular fractions of cultured skin fibroblasts from normal controls $(C)$ and patients with Friedreich's Ataxia $(P)$. spectophotometer. N-acetyl-B-D-glucosaminidase (HEXT) was measured by the method of O'Brien et al. (1970) modified by Delvin et al. (1972) using an Aminco Bowman spectrophotofluorometer. Cell protein was measured by the method of Lowry et al. (1951).

The distribution of $\mathrm{CCO}$ activity was used to calculate the possible contamination of cytosolic $\mathrm{ME}$ by mitochondrial $\mathrm{ME}$ during preparation of the fractions. Thus corrected values for ME-NADP + represent the specific ME activity which should have been found in the mitochondrial and cytosolic fractions if all the $\mathrm{CCO}$ activity were restricted to mitochondria.

\section{ReSULTS}

Results of the specific activity of ME-NADP + and ME-NAD + dependent are detailed in tables $I$ and 2. Graphic representations are shown in figures 1 and 2.

Tables 3, 4 and 5 give the specific activities of $\mathrm{LDH}, \mathrm{CCO}$ and HEXT. In table 6 appear the results of ME-NADP + activity measured in the same cell lines one week after the initial determination. These same results are illustrated in figure 3 . Corrected values of ME-NADP + are shown in table 7 and figure 4 . Table 8 is a summary of the mean value of all enzymes measured in mitochondrial and cytosolic fractions of cultured skin fibroblasts from patients and controls.

\section{Discussion}

\section{The marker enzymes}

Most of the LDH activity (70-80\%) was recovered in the cytosolic supernatant (table 3). However, we did not use the LDH values to correct for cytosolic contamination of mitochondrial fractions because of an excessively large range of values

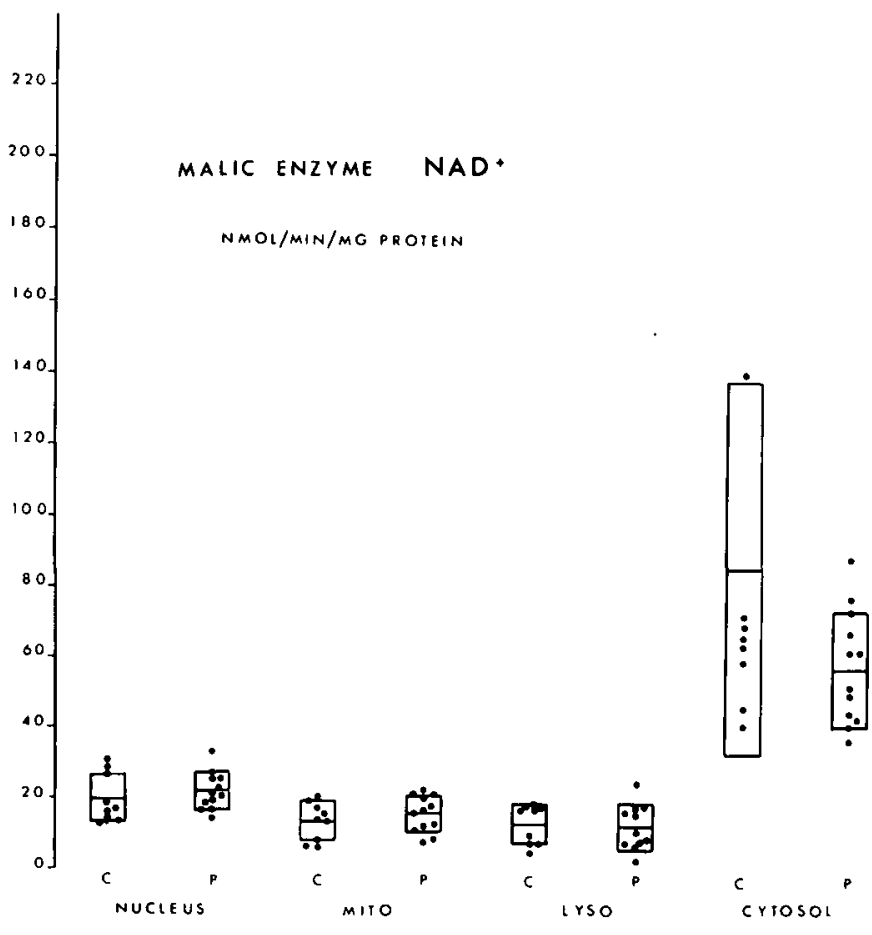

Figure $2-$ Malic enzyme NAD + dependent activity in cellular fractions of cultured skin fibroblasts from normal controls $(C)$ and patients with Friedreich's Ataxia $(P)$. 
and the fact that under the assay conditions used, there was a rapid loss of enzymatic activity with time.

Total hexosaminidase (HEXT) activity in cytosolic fractions was about three times greater than in lysosomal fractions (table 5) suggesting that the differential centrifugation of lysosomes was incomplete. However this does not jeopardize the interpretation of $\mathrm{ME}$ results since no significant amount of $\mathrm{ME}$ is expected to be present in lysosomes.

Cytochrome-C-oxidase $(\mathrm{CCO})$ appeared to be a more reliable marker than the preceding two enzymes with approximately $85 \%$ of the total fibroblasts $\mathrm{CCO}$ activity being clustered around the mitochondrial and lysosomal fractions (table 4). The distribution ratio of $\mathrm{CCO}$ between mitochondria and cytosol was 19 to 1 with about $5 \%$ contamination of cytosolic by mitochondrial $\mathrm{CCO}$. For this reason, we have used the $\mathrm{CCO}$ values as a "correcting factor" for the malic enzyme NADP + dependent activity (table 7).

\section{The fractions}

The nuclear fraction had to be considered as a purification fraction since fibroblasts cell membranes as well as intact fibroblasts could be recovered after the first centrifugation. According to the distribution of $\mathrm{CCO}$ activity, the mitochondria were distributed between the mitochondrial and the lysosomic fractions in a ratio of 1.6 to 1 for controls and 1.4 to 1 for patients (table 4).

\section{Malic enzyme}

The mean specific activity of ME-NADP + was comparable between patients and controls whether corrected (Fig. 4) or not corrected (Fig. 1) and stable with time (Fig. 3). The values of ME-NAD + were also comparable (Fig. 2) with the exception of two individual values above the upper standard deviation of the mean in the control group. These results are in contrast with the results of Stumpf et al. (1982) and Bottacchi and Di Donato (1983).

The difference could be due to a number of factors including the choice of patients, the methodology and the interpretation of results.

\section{Choice of patients}

As far as we know the same diagnostic criteria (Geoffroy et al., 1976) were used for the selection of patients in all three studies. Still it is possible that a group of patients belonging to a genetic isolate share a common gene defect which is not to be found in another group. If this were the case, we could conclude that one can suffer from Friedreich's disease without being MEm deficient.

\section{Methodology}

Since we are studying oxidative metabolism in cells cultured under artificial conditions, it is always possible to unveil or mask differences in enzymatic activities pertaining to the absence of standardized tissue culture conditions. For example, adding or not $\mathrm{CO}_{2}$ to the tissue culture flasks may vary the level of mitochondrial enzymes and affect ME activity.

Different techniques of homogenization and centrifugation may also explain the discordant results. Davignon et al. (1979) have postulated the existence of a membrane phospholipids linoleic acid deficiency in FA. Barbeau (1982) has also reported on the rigidity of FA cell membranes.
These changes could result in preferential breakage of FA cell membranes during homogenization with redistribution of the mitochondrial ME activity towards the cytosolic fraction during centrifugation.

\begin{tabular}{ccccc}
\hline \multicolumn{5}{c}{ Table 1: Malic enzyme NADP + dependent activity (nmol/min/mg protein) } \\
\hline \hline & \multicolumn{5}{c}{$\begin{array}{c}\text { MITO- } \\
\text { FRACTION }\end{array}$} & NUCLEUS & CHONDRIA & LYSOSOMES & CYTOSOL \\
Controls & & & & \\
1 & 0.91 & 0.58 & 0.35 & 3.98 \\
2 & 0.85 & 0.98 & 1.10 & 6.79 \\
3 & 2.20 & 1.06 & 1.38 & 11.38 \\
4 & 0.50 & 0.47 & 0.62 & 4.31 \\
5 & 0.82 & 0.93 & 1.10 & 6.26 \\
6 & 1.47 & 1.56 & 1.25 & 6.37 \\
7 & 0.63 & 0.43 & 0.97 & 4.42 \\
8 & 1.25 & 0.43 & 0.35 & 3.70 \\
9 & 0.86 & 0.82 & 0.97 & 2.64 \\
mean \pm SD & $1.05 \pm 0.52$ & $0.81 \pm 0.37$ & $0.89 \pm 0.37$ & $5.53 \pm 2.59$ \\
range & $0.50-2.20$ & $0.43-1.56$ & $0.35 \pm 1.38$ & $2.64-11.38$ \\
Patients & & & & \\
1 & 1.12 & 1.15 & 0.86 & 6.45 \\
2 & 0.75 & 1.22 & 1.38 & 5.83 \\
3 & 0.96 & 0.89 & 0.74 & 7.67 \\
4 & 0.75 & 1.01 & 0.65 & 5.29 \\
5 & 0.88 & 0.64 & 1.08 & 8.01 \\
6 & 1.57 & 0.56 & 0.71 & 7.54 \\
7 & 0.85 & 0.56 & 0.82 & 4.48 \\
8 & 0.97 & 0.92 & 0.72 & 4.14 \\
9 & 1.08 & 0.78 & 0.82 & 5.42 \\
10 & 0.38 & 0.18 & 0.27 & 1.93 \\
11 & 0.77 & 1.16 & 0.80 & 5.89 \\
12 & 0.28 & 0.64 & 0.82 & 4.08 \\
mean \pm SD & $0.86 \pm 0.32$ & $0.81 \pm 0.30$ & $0.80 \pm 0.25$ & $5.56 \pm 1.75$ \\
range & $0.28-1.57$ & $0.18-1.16$ & $0.27-1.38$ & $1.93-8.01$ \\
\hline
\end{tabular}

Table 2: Malic enzyme NAD + dependent activity $(\mathrm{nmol} / \mathrm{min} / \mathrm{mg}$ protein)

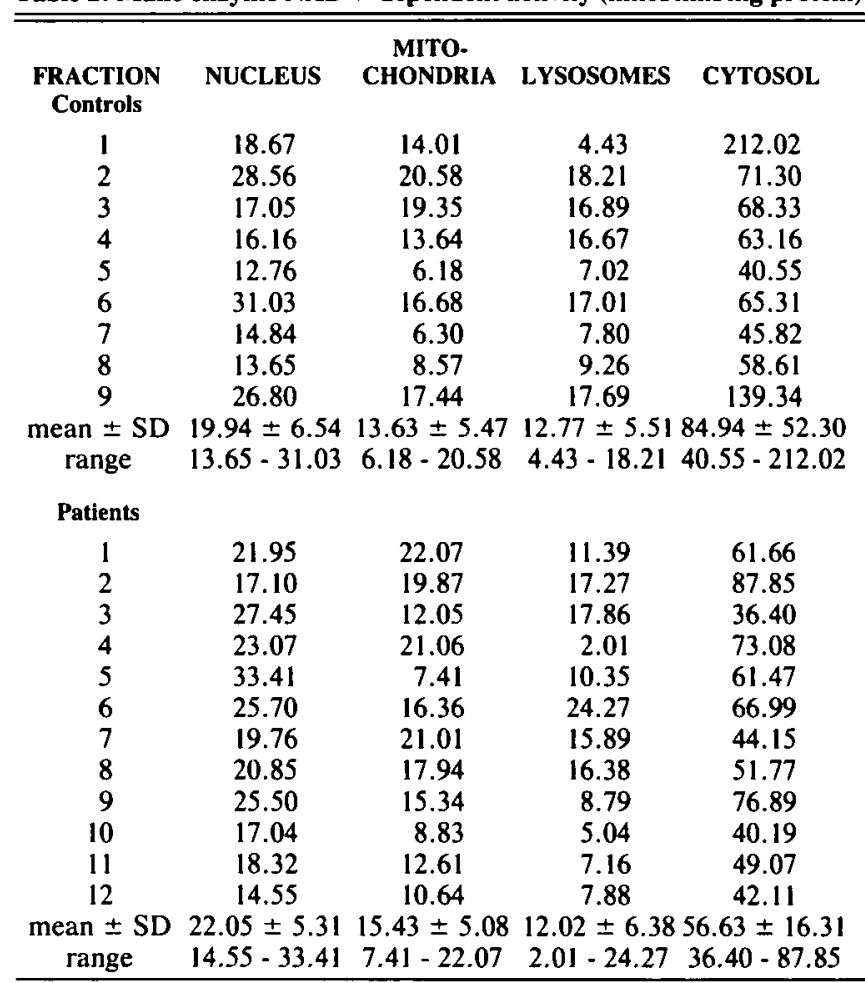


Table 3: Lactate dehydrogenase activity (nmol/min/mg protein)

\begin{tabular}{|c|c|c|c|c|}
\hline $\begin{array}{l}\text { FRACTION } \\
\text { Controls }\end{array}$ & NUCLEUS & $\begin{array}{c}\text { MITO- } \\
\text { CHONDRIA }\end{array}$ & LYSOSOMES & CYTOSOL \\
\hline 1 & 10.89 & 24.73 & 26.52 & 237.64 \\
\hline 2 & 37.13 & 77.44 & 51.51 & 125.82 \\
\hline 3 & 24.90 & 6.53 & 31.99 & 581.51 \\
\hline 4 & 14.70 & 39.49 & 14.29 & 193.78 \\
\hline 5 & 28.37 & 92.85 & 41.72 & 1084.12 \\
\hline 6 & 15.51 & 20.28 & 24.88 & 341.64 \\
\hline 7 & 79.15 & 216.13 & 90.46 & 803.86 \\
\hline 8 & 0.00 & 12.86 & 4.09 & 141.48 \\
\hline 9 & 6.99 & 3.30 & 2.73 & 178.64 \\
\hline $\begin{array}{l}\text { mean } \pm S D \\
\text { range }\end{array}$ & $\begin{array}{c}24.18 \pm 23.53 \\
0.00-79.15\end{array}$ & $\begin{array}{c}54.29 \pm 68.22 \\
3.30-216.13\end{array}$ & $\begin{array}{c}32.02 \pm 27.20 \\
2.73-90.46\end{array}$ & $\begin{array}{l}409.83 \pm 340.31 \\
125.82-1084.12\end{array}$ \\
\hline \multicolumn{5}{|l|}{ Patients } \\
\hline 1 & 4.12 & 16.36 & $11.0 !$ & 88.09 \\
\hline 2 & 11.40 & 60.06 & 44.30 & 167.73 \\
\hline 3 & 101.95 & 531.34 & 89.32 & 583.93 \\
\hline 4 & 31.43 & 25.74 & 29.85 & 850.36 \\
\hline 5 & 46.98 & 492.58 & 188.16 & 266.37 \\
\hline 6 & 33.26 & 14.63 & 26.51 & 1719.36 \\
\hline 7 & 15.88 & 16.56 & 15.19 & 164.79 \\
\hline 8 & 20.18 & 26.39 & 1.97 & 776.61 \\
\hline 9 & 33.39 & 56.16 & 36.93 & 256.89 \\
\hline 10 & 20.97 & 14.73 & 17.26 & 28.63 \\
\hline 11 & 9.36 & 11.98 & 11.78 & 68.81 \\
\hline 12 & 10.41 & 8.35 & 9.46 & 489.97 \\
\hline $\begin{array}{l}\text { mean } \pm S D \\
\text { range }\end{array}$ & $\begin{array}{c}28.51 \pm 25.27 \\
4.12-101.95\end{array}$ & $\begin{array}{c}103.74 \pm 184.42 \\
8.35-531.34\end{array}$ & $\begin{array}{c}40.14 \pm 52.08 \\
1.97-188.16\end{array}$ & $\begin{array}{l}454.87 \pm 484.77 \\
28.63-1719.36\end{array}$ \\
\hline
\end{tabular}

Table 5: Total hexosaminidase activity ( $\mathrm{nmol} / \mathrm{min} / \mathrm{mg}$ protein)

\begin{tabular}{|c|c|c|c|c|}
\hline $\begin{array}{l}\text { FRACTION } \\
\text { Controls }\end{array}$ & NUCLEUS & $\begin{array}{c}\text { MITO- } \\
\text { CHONDRIA }\end{array}$ & LYSOSOMES & CYTOSOL \\
\hline 1 & 92.38 & 97.60 & 19.46 & 159.50 \\
\hline 2 & 72.60 & 170.22 & 67.75 & 224.78 \\
\hline 3 & 102.20 & 159.15 & 85.17 & 132.00 \\
\hline 4 & 96.35 & 61.22 & 17.28 & 152.64 \\
\hline 5 & 52.11 & 13.97 & 21.26 & 105.11 \\
\hline 6 & 67.69 & 102.88 & 60.53 & 96.15 \\
\hline 7 & 53.83 & 13.60 & 9.30 & 71.04 \\
\hline 8 & 28.75 & 32.09 & 39.08 & 165.45 \\
\hline 9 & 87.06 & 93.29 & 69.12 & 306.51 \\
\hline $\begin{array}{l}\text { mean } \pm S D \\
\text { range }\end{array}$ & $\begin{array}{l}72.55 \pm 24.39 \\
28.75-102.20\end{array}$ & $\begin{array}{l}82.66 \pm 57.84 \\
13.92-170.22\end{array}$ & $\begin{array}{c}43.23 \pm 27.85 \\
9.50-85.17\end{array}$ & $\begin{array}{c}157.02 \pm 71.98 \\
96.18-306.51\end{array}$ \\
\hline \multicolumn{5}{|l|}{ Patients } \\
\hline 1 & 87.59 & 133.06 & 47.95 & 227.43 \\
\hline 2 & 216.41 & 217.33 & 97.48 & 536.90 \\
\hline 3 & 151.86 & 145.27 & 58.80 & 246.68 \\
\hline 4 & 146.86 & 133.15 & 43.40 & 229.30 \\
\hline 5 & 94.68 & 98.09 & 123.80 & 181.81 \\
\hline 6 & 89.55 & 94.25 & 42.80 & 81.82 \\
\hline 7 & 97.37 & 107.13 & 50.57 & 122.20 \\
\hline 8 & 59.48 & 98.32 & 127.25 & 140.46 \\
\hline 9 & 87.97 & 157.67 & 23.74 & 58.29 \\
\hline 10 & 52.24 & 28.08 & 12.16 & 31.25 \\
\hline 11 & 27.50 & 58.64 & 38.14 & 149.63 \\
\hline 12 & 81.48 & 46.44 & 36.57 & 139.61 \\
\hline $\begin{array}{c}\text { mean } \pm S D \\
\text { range }\end{array}$ & $\begin{array}{l}99.41 \pm 50.80 \\
27.50-216.41\end{array}$ & $\begin{array}{c}109.78 \pm 52.24 \\
28.08-217.33\end{array}$ & $\begin{array}{l}58.55 \pm 37.42 \\
12.16-127.25\end{array}$ & $\begin{array}{c}178.78 \pm 131.60 \\
31.25-536.90\end{array}$ \\
\hline
\end{tabular}

Table 4: Cytochrome-C-Oxidase activity (nmol/min/mg protein)

\begin{tabular}{ccccc}
\hline \hline $\begin{array}{c}\text { FRACTION } \\
\text { Controls }\end{array}$ & NUCLEUS & $\begin{array}{c}\text { MITO- } \\
\text { CHONDRIA }\end{array}$ & LYSOSOMES & CYTOSOL \\
1 & & & & \\
2 & 0.65 & 6.33 & 1.75 & 0.55 \\
3 & 2.20 & 8.58 & 7.10 & 0.50 \\
4 & 1.15 & 7.51 & 6.21 & 0.11 \\
5 & 3.36 & 6.68 & 3.43 & 0.24 \\
6 & 2.79 & 10.27 & 6.59 & 0.00 \\
7 & 1.43 & 8.17 & 4.60 & 0.30 \\
8 & 0.95 & 1.67 & 1.12 & 0.17 \\
9 & 1.00 & 2.90 & 0.92 & 0.00 \\
mean \pm SD & $1.61 \pm 0.94$ & $6.11 \pm 2.95$ & $3.71 \pm 2.47$ & $0.20 \pm 0.20$ \\
range & $0.65-3.36$ & $1.67-10.27$ & $0.92-7.10$ & $0.00-0.55$ \\
Patients & & & & \\
1 & 1.07 & 9.41 & 4.43 & 1.45 \\
2 & 1.92 & 14.88 & 13.40 & 0.00 \\
3 & 1.17 & 3.01 & 3.06 & 0.21 \\
4 & 1.86 & 7.93 & 5.95 & 0.46 \\
5 & 0.77 & 3.78 & 3.70 & 0.73 \\
6 & 1.46 & 6.58 & 4.60 & 0.26 \\
7 & 1.24 & 8.46 & 6.27 & 0.24 \\
8 & 1.96 & 8.13 & 6.77 & 0.37 \\
9 & 1.79 & 5.78 & 2.06 & 0.18 \\
10 & 0.80 & 1.39 & 1.72 & 0.07 \\
11 & 0.13 & 1.57 & 1.33 & 0.49 \\
12 & 1.57 & 3.86 & 2.71 & 0.32 \\
mean \pm SD & $1.31 \pm 0.55$ & $6.23 \pm 3.85$ & $4.66 \pm 3.28$ & $0.39 \pm 0.38$ \\
range & $0.13-1.96$ & $1.39-14.88$ & $1.33-13.40$ & $0.00-1.45$ \\
\hline & & & &
\end{tabular}

Table 6: Repeat determination of malic enzyme NADP + dependent activity ( $\mathrm{nmol} / \mathrm{min} / \mathrm{mg}$ protein)

\begin{tabular}{ccccc}
\hline $\begin{array}{c}\text { FRACTION } \\
\text { Controls }\end{array}$ & NUCLEUS & $\begin{array}{c}\text { MITO- } \\
\text { CHONDRIA }\end{array}$ & LYSOSOMES & CYTOSOL \\
I & 0.51 & 0.37 & - & 2.41 \\
2 & 1.38 & 2.15 & 2.50 & 6.74 \\
3 & 1.68 & - & 1.09 & 7.06 \\
4 & 0.47 & 0.51 & 0.85 & 5.51 \\
5 & 0.68 & 0.74 & 1.26 & 5.68 \\
6 & 1.20 & 1.25 & 1.17 & 5.00 \\
7 & - & - & - & - \\
8 & 1.38 & 0.96 & 0.70 & 4.29 \\
9 & 1.51 & 0.68 & 0.85 & 3.75 \\
mean \pm SD & $1.10 \pm 0.47$ & $0.95 \pm 0.60$ & $1.20 \pm 0.60$ & $5.05 \pm 1.54$ \\
range & $0.47-1.68$ & $0.37-2.15$ & $0.70-2.50$ & $2.41-7.06$ \\
Patients & & & & \\
1 & 0.70 & 0.63 & 0.57 & 4.03 \\
2 & 1.25 & 1.72 & 1.81 & 9.72 \\
3 & 1.41 & 0.57 & 0.95 & 10.86 \\
4 & 0.86 & 1.17 & 0.78 & 6.17 \\
5 & 0.88 & 0.68 & 1.10 & 10.02 \\
6 & 1.59 & 0.55 & 0.71 & 7.20 \\
7 & 0.55 & 0.50 & 0.67 & 10.29 \\
8 & 0.61 & 0.85 & 0.74 & 7.14 \\
9 & 0.96 & 0.82 & 0.65 & 3.98 \\
10 & 0.86 & 0.44 & 0.62 & 5.13 \\
11 & 0.73 & 0.36 & 0.68 & 3.22 \\
12 & 0.70 & 0.50 & 0.91 & 1.99 \\
mean \pm SD & $0.92 \pm 0.32$ & $0.73 \pm 0.38$ & $0.84 \pm 0.33$ & $6.56 \pm 2.97$ \\
range & $0.55-1.59$ & $0.36-1.72$ & $0.57-1.81$ & $1.99-10.86$ \\
\hline & & & &
\end{tabular}


Table 7: Corrected values of malic enzyme NADP + dependent activity (nmol/min/mg protein)

\begin{tabular}{ccc}
\hline $\begin{array}{c}\text { FRACTIONS } \\
\text { Controls }\end{array}$ & MITOCHONDRIA & CYTOSOL \\
1 & 0.58 & \\
2 & 0.98 & 4.30 \\
3 & 1.06 & 7.15 \\
4 & 0.47 & 11.53 \\
5 & 0.92 & 4.30 \\
6 & 1.56 & 4.14 \\
7 & 0.43 & 6.55 \\
8 & 0.43 & 4.87 \\
9 & 0.82 & 3.70 \\
mean \pm SD & $0.81 \pm 0.37$ & 2.64 \\
range & $0.43-1.56$ & $5.46 \pm 2.66$ \\
Patients & & $2.64-11.53$ \\
1 & 1.15 & \\
2 & 1.22 & 7.42 \\
3 & 0.89 & 5.83 \\
4 & 1.01 & 8.18 \\
5 & 0.64 & 5.54 \\
6 & 0.56 & 9.78 \\
7 & 0.56 & 7.83 \\
8 & 0.92 & 4.59 \\
9 & 0.78 & 4.29 \\
10 & 0.18 & 5.57 \\
11 & 1.16 & 2.02 \\
12 & 0.64 & 8.04 \\
mean \pm SD & $0.81 \pm 0.30$ & 4.39 \\
range & $0.18-1.22$ & $6.12 \pm 2.17$ \\
\hline & & $2.02-9.78$ \\
\hline & &
\end{tabular}

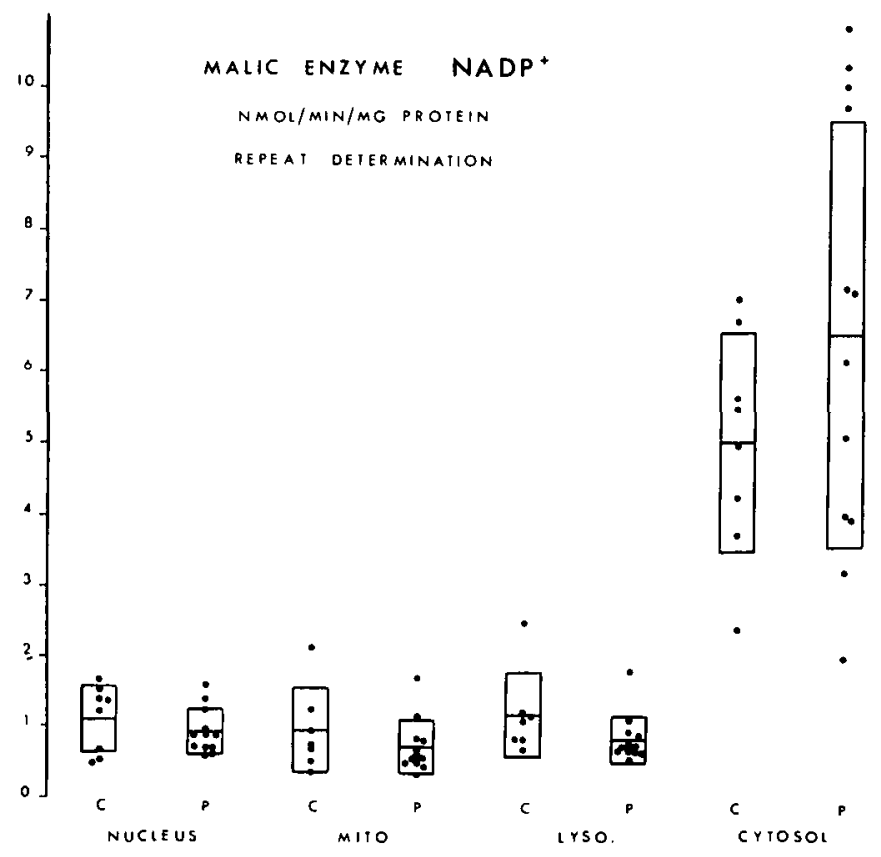

Figure 3 - Repeat determination of malic enzyme NADP + dependent activity in cellular fractions of cultured skin fibroblasts from normal controls $(C)$ and patients with Friedreich's Ataxia $(F)$.
Table 8: Malic enzyme (ME), lactate dehydrogenase (LDH), cytochromeC-oxidase (CCO) and total hexosaminidase (HEXT) activity in mitochondrial (m) and cytosolic (c) fractions of cultured skin fibroblasts (nmol/min/mg protein)

\begin{tabular}{lcc}
\hline \hline MITOCHONDRIAL & CONTROLS & PATIENTS \\
ME-NADP+ & $0.81 \pm 0.37$ & $0.81 \pm 0.30$ \\
ME-NADP+(REPEAT) & $0.95 \pm 0.60$ & $0.73 \pm 0.38$ \\
ME-NAD+ & $13.63 \pm 5.47$ & $15.43 \pm 5.08$ \\
LDH & $54.29 \pm 68.22$ & $103.74 \pm 184.42$ \\
HEXT & $82.66 \pm 57.84$ & $109.78 \pm 52.24$ \\
CCO & $6.11 \pm 2.95$ & $6.23 \pm 3.85$ \\
$\quad$ & \\
$\quad$ CYTOSOLIC & & \\
ME-NADP+ & $5.53 \pm 2.59$ & $5.56 \pm 1.75$ \\
ME-NADP+ & & \\
(CORRECTED) & $5.46 \pm 2.66$ & $6.12 \pm 2.17$ \\
ME-NADP+(REPEAT) & $5.05 \pm 1.54$ & $6.56 \pm 2.97$ \\
ME-NAD+ & $84.94 \pm 52.30$ & $56.63 \pm 16.31$ \\
LDH & $409.83 \pm 340.31$ & $454.87 \pm 484.77$ \\
HEXT & $157.02 \pm 71.98$ & $178.78 \pm 131.60$ \\
CCO & $0.20 \pm 0.20$ & $0.39 \pm 0.38$ \\
\hline
\end{tabular}

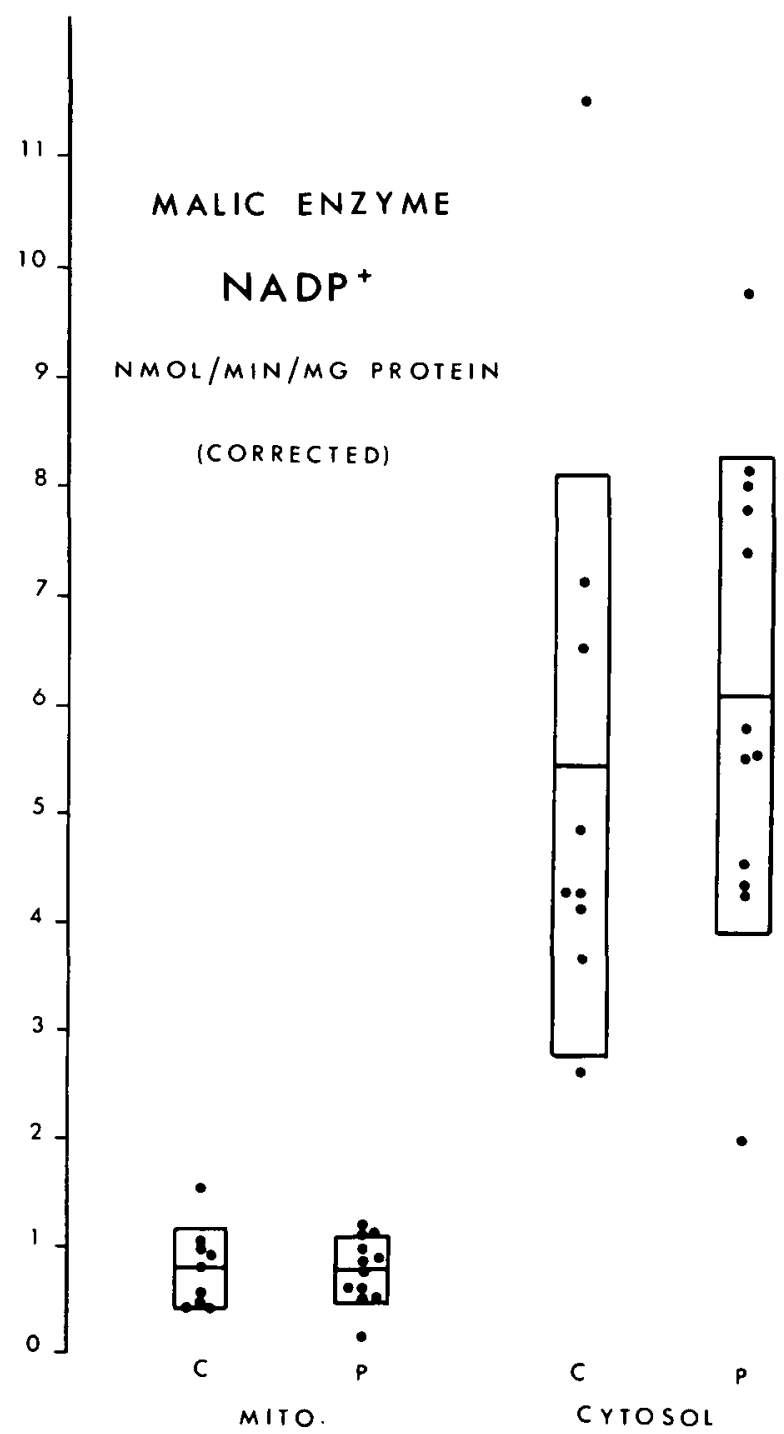

Figure 4-Corrected values for mitochondrial contamination of cytosolic malic enzyme NADP + dependent activity. 


\section{Interpretation of results}

From Stumpf's own data (1982), we calculated that the activity of mitochondrial succinate: cytochrome-C-reductase $(\mathrm{SCRm})$ was 30 percent lower in patients with FA than in normal controls. Had SCRm, a mitochondrial marker, been used instead of LDH, a cytosolic marker, to correct for MEm activity, the degree of deficiency would have been less impressive, although probably still significant (table 9 ).

For the same reason, we observed no difference in $\mathrm{MEm}$ activity between our patients and controls because of comparable levels of mitochondrial marker enzyme in both groups (table 9).

Table 9: Mitochondrial malic enzyme and marker enzymes in Friedreich's ataxia ( $\mathrm{nmol} / \mathrm{min} / \mathrm{mg}$ protein)

\begin{tabular}{lcccc}
\hline \hline AUTHORS & ENZYME & PATIENTS & CONTROLS & RATIO P/C \\
Stumpf & MEm & $0.29 \pm 0.17$ & $1.32 \pm 0.73$ & 0.22 \\
(1982) & SCRm & $21 \pm 8$ & $30 \pm 12$ & 0.70 \\
Present & MEm & $0.81 \pm 0.30$ & $0.81 \pm 0.37$ & 1.00 \\
& CCOm & $6.23 \pm 3.8$ & $6.11 \pm 2.95$ & 1.02 \\
Bottacchi & MEm & $0.52 \pm 0.33$ & $1.57 \pm 0.35$ & 0.33 \\
$(1983)$ & CCOm & $194 \pm 38$ & $240 \pm 94$ & 0.80 \\
\hline
\end{tabular}

We cannot compare our results using skin fibroblasts with the results of Bottacchi and Di Donato (1983) who used skeletal muscle biopsies. However their data also show a 20 percent reduction in the activity of mitochondrial $\mathrm{CCO}$ in patients as compared with controls.

In conclusion, our study could not confirm the presence of a decreased mitochondrial $\mathrm{ME}$ in fibroblasts of patients with FA as reported by Stumpf et al . (1982) and Bottacchi and Di Donato (1983). We believe that the choice of patients and controls is not a significant factor pertaining to the difference in results. Methodological differences are more likely explanatory of the contrasting results, particularly with regard to preparation of homogenates and differential centrifugation. This problem is not yet resolved and therefore it is too early to assume that mitochondrial malic enzyme deficiency is the primary metabolic defect leading to Friedreich's disease.

\section{ACKNOWLEDGEMENTS}

This research was supported by grants from l'Association canadienne de l'Ataxie de Friedreich, le Réseau de Médecine Génétique du Québec et le Fonds de Recherche en Santé du Québec. We are grateful to
Elizabeth Ledru, Gisèle Fontaine, Bernard Grignon, Sylvie Beaulieu and Ginette Préfontaine for their contribution to this work.

\section{REFERENCES}

Barbeau A, Butterworth RF, Ngo T, Breton B, Melançon SB, Shapcott D, Geoffroy G and Lemieux B (1976) Pyruvate metabolism in Friedreich's ataxia. Can J Neurol Sci 3: 379-388.

Barbeau A (1982) Friedreich's disease 1982: Etiologic hypotheses. A personal analysis. Can J Neurol Sci 9: 243-263.

Blass JP, Kark RAP and Menon NK (1976) Low activities of the pyruvate and oxoglutarate dehydrogenase complexes in five patients with Friedreich's Ataxia. New Engl J Med 295: 62-67.

Bottacchi, E. and Di Donato, S. (1983) Skeletal muscle NAD+ and NADP + dependent malic enzyme in Friedreich's Ataxia. Neurology 33: 712-716.

Davignon J, Huang YS, Wolf JP and Barbeau A (1979) Fatty acid profile of major lipid classes in plasma lipoproteins of patients with Friedreich's ataxia. Demonstration of a low linoleic acid content most evident in the cholesterol-ester fraction. Can J Neurol Sci 6 : 275-283.

Delvin ED, Scriver CR, Potier A, Clow CL and Goldman H (1972) Maladie de Tay-Sachs: Dépistage et diagnostic prénatal. Union Méd Canada 101: 683.

Geoffroy G, Barbeau A, Breton G, Lemieux B, Aubé M, Léger C and Bouchard JP (1976) Clinical description and roentgenologic evaluation of patients with FA. Can J Neurol Sci 4: 279-286.

Kark RAP, Rodriguez-Budelli MM, Becker DM. Weiner LP and Forsythe AB (1977) Lipoamide dehydrogenase: rapid heat inactivation in platelets of patients with recessively inherited ataxia. Neurology 31: 199-202.

Lin RC and Davis EJ (1974) Malic enzymes in rabbit heart mitochondria. Separation and comparison of some characteristic of a NAD-preferring and a NADP-specific enzyme. J Biol Chem 249: 3867-3875.

Lowry O, Rosebrough N, Farr A and Randall RJ (1951) Protein measurement with the Folin phenol reagent. J Biol Chem 193 265-275.

Melançon SB, Potier M, Dallaire L, Rollin P, Fontaine G and Grenier B (1979) Pyruvate dehydrogenase, Lipoamide dehydrogenase and citrate synthase activities in fibroblasts from patients with Friedreich's and Charlevoix-Saguenay ataxia. Can J Neurol Sci 6: 241-242.

Melançon SB, Potier M, Dallaire L, Fontaine G, Grenier B, Lemieux $B$, Geoffroy $G$ and Barbeau A (1978) Lipoamide dehydrogenase in Friedreich's ataxia fibroblasts. Can J Neurol Sci 5: 115-118.

O'Brien JS, Okada S, Chen A and Fillerup DL (1970) Tay-Sachs disease. Detection of heterozygotes and homozygotes by serum hexosaminidase assay. New Engl J Med 283: 15.

Sottocasa GL, Kuylenstierna B, Eruster E and Bergstrand A (1967) An electron transport system associated with the outer membrane of liver mitochondria. J Cell Biol 32: 415.438.

Stumpf DA and Parks JK (1979) Friedreich ataxia II: Normal kinetics of lipoamide dehydrogenase. Neurology 29: 820-826.

Stumpf DA, Parks JK, Eguren LA and Haas R (1982) Friedreich ataxia III: Mitochondrial malic enzyme deficiency. Neurology 32: 221-227.

Stumpf DA, Parks JK and Parker WD (1983) Friedreich's disease IV: Reduced mitochondrial malic enzyme activity in heterozygotes. Neurology 33: 780-783. 